\title{
Peningkatan Kemampuan Berbicara Bahasa Inggris melalui Lagu di Sekolah Dasar Rumah Peduli, Yayasan Hijau-Pasar Minggu
}

\author{
Yunita $^{1}$, I. Aeni Muharromah ${ }^{2}$ \\ Universitas Pamulang 1,2 \\ Korespondensi: dosen02584@unpam.ac.id ${ }^{1}$, dosen00034@unpam.ac.id
}

\begin{abstract}
Teaching English for elementary school students is different from teenagers or adults. Elementary school students have their own uniqueness and characteristics that more or less affect the learning atmosphere in the classroom and the teacher's selection of learning strategies. Among the strategies for teaching English to children that teachers can opt for using songs. Songs are an authentic source of language. There is almost no time limit in using songs as media to teach English, meaning that students can use songs as language input as they like, whenever they want, both inside and outside the classroom. Having looked at that, the Community Service team from the English Literature Study Program, Universitas Pamulang intends to carry out Community Service (PkM) with the theme "Improving English Speaking Ability Using Songs at Rumah Peduli Elementary School (Yayasan Indonesia Hijau-Pasar Minggu)". The selection of target partners in the form of children's study groups is based on the consideration that children are the next generation who will continue the course of the nation's life in the future. Thus, they need to be equipped with the formation of abilities from an early age which can be very useful for the future.
\end{abstract}

Keywords: elementary school students, song, English Speaking skills, Rumah Peduli

\begin{abstract}
Abstrak
Pengajaran bahasa Inggris untuk siswa sekolah dasar tentunya tidak sama dengan pengajaran bahasa ini untuk remaja maupun orang dewasa. Siswa sekolah dasar memiliki keunikan dan karakteristiknya sendiri yang sedikit banyak mempengaruhi suasana pembelajaran di dalam kelas dan pemilihan metode pembelajaran yang dilakukan oleh guru. Salah satu metode pengajaran bahasa Inggris untuk anak-anak yang bisa digunakan oleh para guru adalah pengajaran dengan mengunakan media lagu berbahasa Inggris. Karena lagu merupakan sumber bahasa yang otentik. Hampir tidak ada batas waktu dalam menggunakan media lagu untuk mengajar ataupun belajar bahasa Inggris. Dengan menggunakan lagu para siswa mendapatkan input bahasa yang sesuai dengan hati mereka, kapan dan dimana pun mereka mau, baik di dalam kelas maupun di luar kelas. Berangkat dari hal tersebut, maka tim Pengabdian kepada Masyarakat dari Program Studi Sastra Inggris Universitas Pamulang bertujuan untuk melaksanakan kegiatan Pengabdian Kepada Masyarakat (PkM) dengan tema "Peningkatan Kemampuan Berbicara Bahasa Inggris Dengan Menggunakan Lagu di Sekolah Dasar Rumah Peduli (Yayasan Indonesia Hijau-Pasar Minggu)". Pemilihan mitra sasaran berupa kelompok belajar anak-anak tersebut berdasarkan pertimbangan bahwa anak-anak merupakan generasi penerus yang melanjutkan jalannya kehidupan bangsa di masa mendatang. Dengan demikian, mereka perlu dibekali dengan pembentukan kemampuan semenjak dini yang kelak bermanfaat bagi masa depan.
\end{abstract}

Kata kunci: siswa SD, lagu, kemampuan berbicara Bahasa Inggris, Rumah Peduli 


\section{A. Pendahuluan}

Era globalisasi dicirikan sebagai perubahan perkembangan dan kemajuan teknologi di setiap aspek. Dari ciri tersebut, salah satunya adalah dengan terjadi pertukaran informasi lintas negara melalui berbagai media. Globalisasi di negara kita menjadi satu istilah yang saat ini sangat didengungkan mengingat akses yang ditimbulkannya di dalam setiap aspek kehidupan bangsa. Penguasaan bahasa Inggris sebagai bahasa internasional menjadi salah satu syarat penting untuk dikuasai oleh generasi muda agar mereka tidak hanya mampu bertahan, tetapi juga mampu bersaing dengan bangsa lain di era ini yaitu era revolusi industri. Salah satu bahasa asing yang mendapat perhatian cukup serius dari pemerintah dan masyarakat secara luas adalah bahasa Inggris. Bahasa asing ini menjadi bahasa yang sangat signifikan dan salah satu bukti keistimewaannya adalah pemerintah mewajibkan mata pelajaran bahasa Inggris di tingkat sekolah menengah. Bahkan, ada banyak di sekolah dasar tertentu, bahasa Inggris mulai diajarkan sebagai mata pelajaran wajib dan tambahan.

Pengajaran bahasa Inggris untuk siswa sekolah dasar tentunya tidak sama dengan pengajaran bahasa ini untuk remaja maupun orang dewasa. Siswa sekolah dasar memiliki keunikan dan karakteristiknya sendiri yang sedikit atau banyak dapat memengaruhi suasana pembelajaran di dalam kelas dan pemilihan metode pembelajaran yang dilakukan oleh guru. Salah satu metode pengajaran bahasa Inggris untuk anak-anak yang bisa digunakan oleh para guru yaitu pembelajaran dengan mengunakan media lagu berbahasa Inggris. Lagu merupakan sumber bahasa yang otentik. Hampir tidak ada batasan waktu dalam menggunakan media ini untuk mengajar atau belajar bahasa Inggris karena para siswa bisa menggunakan lagu sebagai input bahasa kapan dan dimana pun mereka berada, sesuka hati mereka, baik di dalam kelas maupun di luar kelas. Mereka bisa menyanyikan lagu-lagu tersebut kapan dan dimana saja mereka menginginkannya. Mereka dapat bersentuhan secara cepat dengan bahasa Inggris dan menikmati proses ini secara alamiah.

Brown (2000) mengemukakan salah satu prinsip pembelajaran bahasa yaitu automaticity. Menurut Brown, faktor yang cenderung menghambat kemunculan automaticity ini adalah terlalu berlebihan dalam menganalisa bahasa, terlalu banyak berfikir tentang forms (struktur/grammar) dan terlalu mengingat aturan bahasa. Dalam hal ini, lagu dapat membantu terjadinya automatic processing of language sehingga siswa melakukan sebuah kegiatan belajar tanpa mereka sengaja. Kegiatan PkM ini memaparkan kelebihan dari menggunakan lagu untuk membantu pembelajaran bahasa Inggris dan bagaimana cara menggunakan lagu di dalam kelas bahasa Inggris bagi anak-anak serta karakteristik anak-anak sebagai pembelajar bahasa asing.

Berangkat dari hal tersebut, maka tim Pengabdian kepada Masyarakat dari Program Studi Sastra Inggris Universitas Pamulang bertujuan untuk melaksanakan kegiatan Pengabdian kepada Masyarakat $(\mathrm{PkM})$ dengan tema "Peningkatan Kemampuan Berbicara Bahasa Inggris Dengan Menggunakan Lagu di Sekolah Dasar Rumah Peduli (Yayasan Indonesia Hijau-Pasar Minggu)". Pemilihan mitra sasaran yaitu kelompok belajar anak-anak. Pemilihan tersebut ialah berdasarkan

ACITYA BHAKTI, Volume 2 Nomor 1, Februari 2022 
pertimbangan bahwa anak-anak merupakan generasi penerus yang melanjutkan jalannya kehidupan bangsa di masa mendatang. Mereka perlu dibekali dengan pembentukan kemampuan semenjak dini yang kelak dapat sangat bermanfaat bagi masa depan. Dalam perkembangannya, Sekolah Rumah Peduli yang beralamatkan di Jalan Kebagusan I, RT.6/RW.1 Pasar Minggu, aktif menyelenggarakan kegiatankegiatan sosial yaitu berupa kegiatan belajar mengajar, juga kegiatan bakti sosial secara rutin di hari-hari peringatan tertentu maupun secara kegiatan insidental. Beberapa kegiatan lainnya yaitu kegiatan santunan anak yatim, penyembelihan hewan kurban, dan pemberian perlengkapan alat sekolah.

Berdasarkan paparan di atas, dapat diketahui bahwa Sekolah Rumah Peduli telah banyak aktif melakukan kegiatan-kegiatan positif yang bermanfaat bagi lingkungan dan masyarakat sekitarnya. Hal ini akan sangat bermafaat untuk masa depan bangsa terutama untuk pembentukan generasi bangsa, dimana mereka dibekali dengan kemampuan dan keterampilan untuk menghadapi dunia pekerjaan kelak. Dengan demikian, kegiatan PkM berupa pelatihan berbicara bahasa Inggris dengan menggunakan lagu menjadi relevan untuk dilakukan.

\section{B. Pelaksanaan dan Metode}

Berdasarkan paparan mengenai analisis situasi dan permasalahan mitra sebagaimana telah diuraikan pada bagian sebelumnya, dapat dilihat bahwa permasalahan yang ditemukan terkait dua hal, yakni permasalahan yang bersifat substantif serta permasalahan yang bersifat teknis. Permasalahan yang bersifat substantif terkait dengan latar belakang serta analisis situasi, yang berimplikasi pada urgensi mengapa kegiatan PkM perlu dilakukan. Sementara itu, permasalahan yang bersifat teknis terkait dengan prosedur atau segala sesuatu yang terkait dengan pelaksanaan kegiatan PkM. Pada bagian ini akan dipaparkan mengenai solusi permasalahan yang ditemukan, yang meliputi aspek substantif dan aspek teknis.

Pertama, solusi permasalahan yang bersifat substantif. Beberapa permasalahan substantif yang ditemukan di antaranya ialah: (1) Aspek teoretis yaitu hal-hal yang berkaitan dengan teknik-teknik dasar menyampaikan lagu untuk peserta didik dengar dan kiat-kiat menarik perhatian peserta didik agar pembelajaran menjadi menyenangkan juga memudahkan, dan (2) Aspek praktis yang berkaitan dengan kegiatan praktik dan simulasi yang dilakukan oleh mahasiswa-mahasiswa Universitas Pamulang terhadap peserta didik kalangan Sekolah Dasar Rumah Peduli. Apabila semakin banyak praktik yang dilakukan, niscaya keterampilan para mahasiswa tersebut akan semakin terarah dalam mengajar dan kemampuan berbicara bahasa Inggris para peserta didik akan meningkat. Terlebih lagi, penggunaan bahasa Inggris menjadi begitu penting untuk dapat mengikuti arus perkembangan dan beradaptasi terhadap globalisasi yang semakin maju. Sebagai generasi muda dan penurus bangsa tentunya mereka yaitu baik peserta didik di Sekolah Dasar Rumah Peduli maupun

ACITYA BHAKTI, Volume 2, Nomor 1, Februari 2022 
mahasiswa Universitas Pamulang dituntut untuk mampu berbahasa Inggris dengan baik agar dapat beriringan mengikuti perkembangan zaman.

Cameron (2001) mengemukakan bahwa ada beberapa kesalahan yang terjadi mengenai pengajaran bahasa Inggris untuk anak-anak yang berlaku di beberapa komunitas sosial. Salah satunya, guru di tingkat sekolah dasar jarang mendapatkan pelatihan yang memadai, dan gaji yang lebih rendah dibandingkan tingkat sekolah lainnya. Menurut Cameron, guru sekolah dasar harus mempunyai wawasan dan pengetahuan yang baik tentang cara bagaimana mengelola siswa dan mereka harus berwawasan tentang bahasa Inggris itu sendiri, mengetahui tentang cara pengajaran dan pembelajaran bahasa. Cameron juga menambahkan, anak-anak tidak hanya membutuhkan bahasa yang sederhana tetapi seringkali mereka menginginkan bahasa yang kompleks. Anak-anak mempunyai potensi kemapuan belajar yang luar biasa, dan terkadang jauh dari yang diperkirakan oleh guru. Dalam hal ini dapat disimpulkan, guru mengajarkan topik yang sederhana saja tentunya tidak cukup, mereka sudah menjadi bagian dari masyarakat global dan banyak diantara mereka yang sudah bisa berbicara tentang hal kompleks seperti komputer, internet, juga dinosaurus (Cameron, 2001). Dengan demikian maka hal ini menjadi penting bagi guru untuk dapat menghubungkan dunia nyata anak-anak dengan mata pelajaran yang mereka ampu, dalam hal ini yaitu bahasa Inggris.

Hal positif dari penggunaan lagu adalah lagu merupakan alat yang sangat baik untuk membantu proses belajar bahasa Inggris untuk anak-anak. Khususnya, lagu diyakini dapat memotivasi siswa selama proses pembelajaran bahasa Inggris. Dapat dikatakan bahwa lagu merupakan bagian penting dari pembelajaran ini karena lagu menjadikan siswa lebih sensitif terhadap bunyi-bunyi yang bermakna. Lagu juga dapat membuat suasana di dalam kelas menjadi- menarik, semarak dan menyenangkan. Saat anak-anak menyukai lagu yang diajarkan guru, mereka akan dengan antusias dan senang hati menyanyikannya, dimana saat itulah mereka sedang mempelajari sesuatu secara tidak langsung.

Brewster (2002, p. 162) berpendapat bahwa ada banyak keuntungan dan manfaat dalam penggunaan lagu sebagai learning resource. Pertama, lagu merupakan linguistic resource. Dalam hal ini, lagu menjadi media pengenalan bahasa baru, sekaligus media untuk penguatan tata bahasa dan kosakata. Lagu juga mempresentasikan bahasa yang sudah dikenali oleh siswa dalam bentuk yang baru serta menyenangkan. Selain itu, secara alamiah lagu memungkinkan terjadinya pengulangan bahasa. Secara integratif lagu dapat dimanfaatkan untuk mengembangkan semua keterampilan bahasa, termasuk meningkatkan kemampuan pengucapan siswa. Kedua, lagu merupakan affective/psychological resource. Selain menyenangkan, lagu dapat memotivasi siswa sekaligus memupuk perilaku yang positif terhadap bahasa Inggris. Lagu bukan merupakan suatu hal yang menakutkan maupun mengancam untuk siswa. Terlebih lagu dapat membantu siswa untuk meningkatkan rasa kepercayaan diri mereka. Sebagai bukti bahwa mereka telah menguasai sesuatu dalam bahasa Inggris, siswa bisa dengan percaya diri menyanyikan lagu berbahasa Inggris di depan orang tua mereka maupun orang lain. Ketiga, lagu

ACITYA BHAKTI, Volume 2 Nomor 1, Februari 2022 
merupakan cognitive resource yaitu lagu dapat meningkatkan konsentrasi, daya ingat dan koordinasi. Siswa menjadi lebih sensitif terhadap tanda rima sebagai alat bantu untuk memaknai sebuah makna. Keempat, lagu dapat menjadi culture resource dan social resource. Brewster (2002) juga menyatakan bahwa lagu dapat memberikan manfaat yang luar biasa bagi pembelajaran pengucapan. Beberapa karakteristik penting pengucapan seperti rhytm dan stress. Secara natural, intonasi dapat dilatih dengan penggunaan lagu.

Pada bagian ini menjelaskan pelaksanaan dan metode pengabdian. Uraian pelaksanaan kegiatan meliputi lokasi, waktu, latar belakang dan banyak peserta. Uraian metode kegiatan meliputi metode dan materi yang disampaikan. Pilihan salah satu atau mengombinasikan beberapa metode kegiatan antara lain: 1) Training/Pelatihan: barang maupun jasa, difusi IPTEK, substitusi IPTEK, atau simulasi IPTEK; 2) Pendidikan berkelanjutan; 3) Penyadaran/ Peningkatan pemahaman terhadap suatu masalah; 4) Pendampingan/ Konsultasi/ Mediasi. Pelakasanaan metode dilakukan oleh para mahasiswa dalam menerapkan pembelajaran berbicra bahasa Inggris dengan menggunakan lagu. Dimana masingmasing mahasiswa yang terdiri dari 5 orang mahasiswa telah memilih metodenya masing-masing. Pemilihan lagu yaitu lagu anak-anak berbahasa Inggris seperti: Twinkle-twinkle, $A B C$, and You are my sun shine. Mahasiswa menjelaskan dan mempraktikan pengucapan setiap lirik lagu beserta artyinya. Untuk lebih lengkapnya bisa disaksikan melalui tautan Youtube berikut ini: https://youtu.be/7tB1-nBupOI.

\section{Hasil dan Pembahasan}

Bagian ini memaparkan mengenai hasil dan pembahasan kegiatan PkM yang telah dilaksanakan oleh tim pengabdi yang terdiri dari beberapa dosen dan mahasiswa Program Studi Sastra Inggris Universitas Pamulang. Karena situasi pandemi virus Corona (COVID-19), maka pelaksanaan kegiatan PkM kali ini bersifat dalam jaringan atau interaksi secara virtual. Meskipun demikian, secara substansial, tema dan tujuan kegiatan PkM tetap dapat dicapai seperti pada rencana awal.

Kegiatan PkM ini bertajuk "Peningkatan Kemampuan Berbicara Bahasa Inggris Dengan Menggunakan Lagu di Sekolah Dasar Rumah Peduli (Yayasan Indonesia Hijau-Pasar Minggu)". Dan oleh karenanya, fokus dari kegiatan PkM ini mencakup 2 hal, yakni (1) Pelatihan pengajaran bahasa Inggris dengan menggunakan lagu dan (2) Peningkatan kemampuan berbicara bahasa Inggris siswa. Dua fokus kegiatan tersebut merupakan manifestasi dari pembelajaran bahasa Inggris yang coba diterapkan Program Studi Sastra Inggris dalam kegiatan Pengabdian kepada Masyarakat. 
Tabel 1. Rangkaian Acara

\begin{tabular}{|c|c|c|c|}
\hline No. & Nama Bagian Video & Narasumber & Keterangan \\
\hline 1. & Greetings & Dr. Yunita, S.S., M.Sas & Pembukaan \\
\hline 2. & Kids Future & Siarno, S.S., M. Pd & $\begin{array}{l}\text { Menjelaskan manfaat bahasa } \\
\text { Inggris untuk masa depan }\end{array}$ \\
\hline 3. & Method & $\begin{array}{l}\text { I. Aeni Muharromah, S.S. } \\
\text { M.M \& Drs. Suwardi, M. M }\end{array}$ & $\begin{array}{l}\text { Menjelaskan metode yang pas untuk } \\
\text { pengajaran bahasa Inggris anak-anak } \\
\text { beserta karakter peserta didik dari } \\
\text { mulai anak-anak, remaja dan dewasa. }\end{array}$ \\
\hline 4. & Teaching & Mahasiswa & Mempraktikan metode pengajaran \\
\hline 5. & Closing & Dr. Yunita, S.S., M.Sas & Rangkuman dan penutup \\
\hline
\end{tabular}

Pembukaan dilakukan oleh Ibu Yunita dengan menyapa para pelajar maupun pengajar yang ingin mempelajari maupun mengajar Bahasa Inggris khususnya untuk anak-anak. Kemudian, kegiatan dilanjutkan oleh Bapak Siarno dengan mensimulasi peserta yang ingin belajar. Bapak Siarno mempraktikkan penggunaan bahasa Inggris. Setelah itu, Ibu Aeni dan Bapak Suwardi menjelaskan secara terperinci mengenai pengajaran bahasa Inggris anak-anak beserta karakter peserta didik dari mulai anakanak, remaja dan dewasa. Lalu, tim mahasiswa masing-masing mempraktikkan metode pengajaran. Sebagai penutup, Ibu Yunita menyampaikan ucapan terimakasih dan memberikan motivasi bagi peserta.

Pada praktiknya, kegiatan PkM kali ini dilaksanakan secara jaringan/virtual melalui media video pembelajaran dan telah dipublikasikan di kanal Youtube yang dibuat oleh tim dosen dan mahasiswa program studi Sastra Inggris Universitas Pamulang. Secara konseptual, video pembelajaran tersebut berisikan beberapa bagian penting yang menjadi poin pembelajaran, yaitu:

\section{Deskripsi Video Pembelajaran:}

(1) bagian pembukaan mengenai pentingnya pembelajaran bahasa Inggris untuk masa depan bagi generasi bangsa (2) metode pembelajaran yang efektif untuk anak-anak (3) metode pembelajaran bahasa Inggris melalui lagu (4) praktik pengajaran dan pembelajaran untuk anak-anak oleh beberapa mahasiswa. 
Peningkatan Kemampuan Berbicara Bahasa Inggris melalui Lagu

\section{Penutup \\ Simpulan}

Kegiatan PkM kali ini menjadi pengalaman yang menarik. Oleh karena situasi yang tidak terelakkan yakni pandemi virus Corona (COVID-19), maka kegiatan PkM yang semula direncanakan berlangsung secara tatap muka diubah menjadi daring atau interaksi virtual melalui video pembelajaran yang dibuat oleh tim dosen dan mahasiswa PkM. Video pembelajaran yang dibuat dan dipublikasikan di kanal Youtube tetap berisikan substansi materi kegiatan PkM sesuai dengan topik yang diajukan, yaitu "Peningkatan Kemampuan Berbicara Bahasa Inggris Dengan Menggunakan Lagu di Sekolah Dasar Rumah Peduli (Yayasan Indonesia Hijau-Pasar Minggu)". Secara garis besar, video yang dibuat berisikan materi tentang metode pembelajaran dan pengajaran bahasa Inggris untuk anak-anak dengan menggunakan media lagu berbahasa Inggris agar pembelajaran menjadi menyenangkan, memudahkan serta efektif. Satu hal yang menarik dari kegiatan PkM kali ini adalah kreatifitas tim dosen dan mahasiswa dalam memodifikasi kegiatan dari metode pembelajaran dan pengajaran ini yang kelak dapat meningkatkan keterampilan khususnya berbicara bahasa Inggris anak-anak. Metode ini tentunya dapat diterapkan dengan kondisi seperti sekarang ketika pandemi dimana banyak hal dituntut untuk menggunakan teknologi digital. Dengan demikian, dapat disimpulkan bahwa kegiatan PkM yang telah dilakukan kali ini dapat mencapai tujuan yang diharapkan, yaitu memberikan pelatihan pembelajaran bahasa Inggris untuk anak-anak dan pengajaran bagi para mahasiswa yang kelak mereka akan menghadapi situasi seperti ini sebagai profesi pilihan mereka dan disesuaikan dengan konteks situasi pandemi.

\section{Saran}

Setelah melakukan evaluasi secara menyeluruh, terdapat beberapa saran yang dapat diberikan agar kegiatan $\mathrm{PkM}$ selanjutnya dapat berlangsung lebih baik. Beberapa saran tersebut di antaranya:

1. Membuat Youtube account atau platform media sosial lain yang dapat mengarsipkan video-video pembelajaran PkM karya program studi Sastra Inggris Universitas Pamulang.

2. Memperbaiki teknik-teknik pembuatan serta editing video supaya video yang dihasilkan dapat ditingkatkan kualitasnya.

3. Mendorong pelatihan yang intensif kepada dosen dan mahasiswa dalam konteks tampil memberikan materi melalui platform video supaya dapat tampil lebih baik dalam video-video pembelajaran.

4. Mendorong para mahasiswa agar lebih baik dalam mempraktekkan public speaking.

5. Mendorong kreativitas dosen dan mahasiswa dalam memodifikasi pengajaran dan pembelajaran bahasa Inggris baik untuk anak-anak maupun remaja. 


\section{DAFTAR PUSTAKA}

Brewster, J., Ellis, G., Girard, D. (2002). The primary English teacher's guide. Penguin English.

Brown, H. D. (2000). Principles of language and teaching. Longman.

Chistamia, V. (2014). Improving students' speaking skill through English song at grade iv of sdn adisucipto ii in the academic year of 2013/2014. Eternal (English,Teaching, Learning, and Research Journal), 4(2).

Ellis, A. (1994). Rational emotive behavior therapy and its applications to emotional education. In A. Ellis \& S. Blau 9Eds.), The Albert Ellis reader: A guide to well-being using rational emotive behavior therapy. 253-260. Citadel Press.

Lynne, C. (2001). Teaching languages to young learners. Cambridge University Press.

Marhnis, Y. (2009). Kiat pembelajaran siswa. Putra Grafika. 